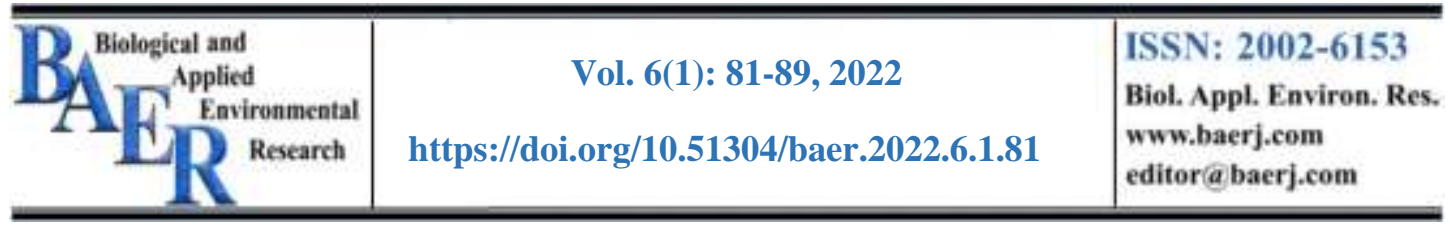

\title{
Effects of Water Temperature on Growth Criteria of Fingerlings of Grass Carp, Ctenopharyngodon idella (Valenciennes, 1884)
}

\begin{abstract}
Majid M. Taher
Aquaculture Unit, College of Agriculture, University of Basrah, Basrah, Iraq

Corresponding author: maj61ae@yahoo.com

Abstract: The current experiment was conducted in the Fish Laboratory of Aquaculture Unit, College of Agriculture, University of Basrah from $28^{\text {th }}$ January to $19^{\text {th }}$ April 2021. Growth criteria of grass carp Ctenopharyngodon idella were investigated using four water temperatures $\left(15,20,25\right.$ and $\left.30^{\circ} \mathrm{C}\right)$. Grass carp fingerlings (4.92 g) were brought from earthen ponds of the Aquaculture Unit in Al-Hartha Station for Agricultural Researches, North Basrah. The results indicated that the highest final weight $(7.96 \mathrm{~g})$ was reached by fishes at $15{ }^{\circ} \mathrm{C}$, while the lowest final weight $(7.22 \mathrm{~g})$ was at $30{ }^{\circ} \mathrm{C}$. Weight increments for fishes were 3.02, 2.97, 2.76 and $2.22 \mathrm{~g}$ for water temperatures of $15,20,25$ and $30{ }^{\circ} \mathrm{C}$, respectively. Fishes had the highest daily growth rate $(0.0425 \mathrm{~g} /$ day $)$ at $15{ }^{\circ} \mathrm{C}$ and the lowest $(0.0312 \mathrm{~g} /$ day $)$ at $300 \mathrm{C}$. Fishes at $20{ }^{\circ} \mathrm{C}$ had the best feed conversion rate of 4.03 , while fishes at $30{ }^{\circ} \mathrm{C}$ had the worst feed conversion rate of 5.29. It can be concluded that the best growth criteria were obtained from fishes at $15{ }^{\circ} \mathrm{C}$ and $20{ }^{\circ} \mathrm{C}$, while the worst was observed at $30{ }^{\circ} \mathrm{C}$.
\end{abstract}

Keywords: Final weight, Weight increment, Daily growth rate, Specific growth rate, Feed conversion rate

\section{Introduction}

Grass carp, Ctenopharyngodon idella was belonged to the family Cyprinidae for a long time, but according to recent phylogenetic studies, Tan \& Armbruster (2018) shifted this fish to the family Xenocypridinae. FAO (2020) stated that grass carp in 2018 was the most widely cultivated freshwater fish species in the world that consisted $10.5 \%$ of world production, followed by silver carp, Hypophthalmichthys molitrix (8.8\%), Nile tilapia, Oreochromis niloticus (8.3\%) and common carp, Cyprinus carpio (7.7\%) from total world production.

It is well known that aquatic plants are an important part of any aquatic ecosystem where they provide habitat for different species of fishes and ensure optimal oxygen regime, while sometimes it is necessary to control these plants, especially in shallow eutrophic ponds. Macrophytes can have a positive and sometimes negative impact on aquatic biotopes (Petr, 2000). Grass carp is an herbivorous fish that feeds on certain aquatic plants and at early life on zooplankton, but in culture conditions, it accepts artificial pelleted feed. Masser 
(2002) stated that when desirable vegetation is unavailable, grass carp fingerling feeds on insect larvae, other invertebrates, and even small numbers of fish fry, while in culture conditions, juveniles feed on pelleted diets and continue to consume this diet throughout their lives. Bozkurt et al. (2017) stated that grass carp exclusively feed on aquatic plants consuming 2-3 times their weight every day.

Grass carp have been introduced since 1945 to many regions in Asia, North America, and virtually all of Europe, mainly for culture and also for controlling aquatic vegetation (Pfeiffer \& Lovell, 1990; Kırkağaç \& Demir, 2006). It is well known that grass carp was introduced in Iraq since 1956. Cudmore \& Mandrak (2004) pointed out that this fish is native to northwestern China and southeastern Russia, and it has been introduced into other countries for controlling vegetation. Durborow et al. (2007) stated that grass carps are used in water ponds to consume undesirable aquatic vegetation and filamentous algae. Silva et al. (2014) stated that grass carp is used to control aquatic plants in Brazil. Dick et al. (2016) revealed that 120 individuals of grass carp per hectare gave better control for plants in the lakes.

Osborne \& Riddle (1999) stated that water temperature and fish size are strongly affected the feeding and growth of grass carp.

Many laboratory experiments were conducted in Iraq on grass carp with few field studies such as Al-Seyab (1996), Saleh et al. (2008), and Taher (2020a) who studied the effects of fish density on growth and condition factor of grass carp cultivated in earthen ponds. Al-Dubakel et al. (2011) studied growth criteria and the implication of grass carp larvae cultivated in a recirculation system. Al-Shkakrchy \& Ahemed (2013) investigated the use of duckweed Lemna spp. in feeding grass and common carp. Talal (2013) investigated the cultivation of grass carp in polluted and non-polluted aquatic environments. Taher (2017) conducted some laboratory experiments on the grass carp. Al-Dubakel et al. (2020) studied the partial replacement of fish meal by Azolla filiculoides meal in grass carp feed. Abdullah et al. (2020) studied the feeding preferences of grass carp for three species of aquatic plants. Taher (2020b) studied the effects of fish weight and water temperature on feed intake of grass carp. The current experiment aimed to investigate the effects of water temperature on growth parameters of grass carp cultivated in the laboratory.

\section{Materials and Methods}

The current experiment was conducted in the aquaria of Fish Laboratory of Aquaculture Unit, College of Agriculture, University of Basrah from $28^{\text {th }}$ January to $19^{\text {th }}$ April 2021. Each aquarium measured $60 \mathrm{~cm}$ in length, $30 \mathrm{~cm}$ in width and $40 \mathrm{~cm}$ in height. In this experiment, four water temperatures $\left(15,20,25\right.$ and $\left.30{ }^{\circ} \mathrm{C}\right)$ were tested with two replicates for each treatment. Grass carp fingerlings $(4.92 \mathrm{~g})$ were brought from earthen ponds of the Aquaculture Unit in Al-Hartha Station for Agricultural Researches, North Basrah. Nine fishes in each aquarium were acclimatized in the laboratory for ten days before the start of the experiment. Aquaria were provided with air pumps and equipped with automatic heaters to control water temperature. The fishes were fed daily at a $3 \%$ feeding rate using commercial pellets prepared by the Agricultural Consultant Office, College of 
Agriculture (fishmeal 20\%, soybean meal 20\%, wheat flour 35\%, wheat bran $23 \%$ and vitamins-minerals premix $2 \%$ ). Fishes were weighed every two weeks and fish feed quantity was changed after each weighing.

Throughout the experiment period, six samples from each treatment were taken to calculate the following equations:

Weight increments (WI, g) $=\mathrm{FW}-\mathrm{IW}$

Daily growth rate $(\mathrm{DGR}, \mathrm{g} /$ day $)=(\mathrm{FW}-\mathrm{IW}) /$ days

Specific growth rate $(\mathrm{SGR}, \% /$ day $)=100 *[(\ln \mathrm{FW})-(\ln \mathrm{IW})] /$ days

$\mathrm{FCR}=$ Feed consumed/ Fish weight increment

Where: $\mathrm{FW}=$ Final fish weight $(\mathrm{g})$; IW = Initial fish weight $(\mathrm{g})$.

Statistical software SPSS IBM (23) and Excel 2013 were used for analyzing the data by least-square analysis.

\section{Results}

Table 1 shows the average fish weight with standard deviation measured during the experiment at different water temperatures. Initial average fish weights ranged from 4.77-5.24 g. The growth parameters for fishes reared at various water temperatures are shown in Table 2. Fishes reared in water temperature of $15{ }^{\circ} \mathrm{C}$ reached the maximum final weight $(7.96 \mathrm{~g})$, whereas fishes reared in water temperature of $30{ }^{\circ} \mathrm{C}$ reached the lowest final weight $(7.22 \mathrm{~g})$ (Figure 1). There were no significant differences ( $>>0.05$ ) between $15^{\circ} \mathrm{C}$ with $20{ }^{\circ} \mathrm{C}$ and $25^{\circ} \mathrm{C}$, while there were significant differences $(\mathrm{p}<0.05)$ between both $15{ }^{\circ} \mathrm{C}$ and $25{ }^{\circ} \mathrm{C}$ with 30 ${ }^{0} \mathrm{C}$, according to statistical analysis of final weight. Weight increments for fishes were $3.02 \mathrm{~g}, 2.97 \mathrm{~g}, 2.76 \mathrm{~g}$ and $2.22 \mathrm{~g}$ for water temperatures of $15^{\circ} \mathrm{C}, 20{ }^{\circ} \mathrm{C}, 2{ }^{\circ} \mathrm{C}$ and $30{ }^{\circ} \mathrm{C}$, respectively (Figure 2). Statistical analysis of weight increments revealed no significant differences ( $>>0.05$ ) between $15{ }^{\circ} \mathrm{C}$ with $20{ }^{\circ} \mathrm{C}$ as well as between $20{ }^{\circ} \mathrm{C}$ and $25{ }^{\circ} \mathrm{C}$, while there were significant differences $(\mathrm{p}<0.05)$ between $15{ }^{\circ} \mathrm{C}$ with $25{ }^{\circ} \mathrm{C}$ and also between $30{ }^{\circ} \mathrm{C}$ with the other three treatments.

Fishes reared in water temperature of $15^{\circ} \mathrm{C}$ had the highest daily growth rate $(0.0425 \mathrm{~g} /$ day $)$, whereas fishes reared in water temperature of $30{ }^{\circ} \mathrm{C}$ had the lowest daily growth rate $(0.0312 \mathrm{~g} /$ day) (Figure 3$)$. Statistical analysis of daily growth rate revealed no significant differences $(\mathrm{p}>0.05)$ between $15{ }^{\circ} \mathrm{C}$ with $20{ }^{\circ} \mathrm{C}$ as well as between $20{ }^{\circ} \mathrm{C}$ and $25{ }^{\circ} \mathrm{C}$, but significant differences $(\mathrm{p}<0.05)$ between $15{ }^{\circ} \mathrm{C}$ with $25{ }^{0} \mathrm{C}$ and $30{ }^{0} \mathrm{C}$ as well as between $25{ }^{\circ} \mathrm{C}$ with $30{ }^{\circ} \mathrm{C}$. Specific growth rates for fishes were $0.6708,0.6848,0.6211$ and $0.5174 \%$ /day for water temperatures of 15 ${ }^{0} \mathrm{C}, 20{ }^{0} \mathrm{C}, 25{ }^{0} \mathrm{C}$ and $30{ }^{\circ} \mathrm{C}$, respectively (Figure 4). Statistical analysis of specific growth rates showed that there were no significant differences $(p>0.05)$ between 15 ${ }^{0} \mathrm{C}$ with $20{ }^{\circ} \mathrm{C}$ and $25{ }^{\circ} \mathrm{C}$, while there were significant differences $(\mathrm{p}<0.05)$ between $30{ }^{0} \mathrm{C}$ with the other three treatments.

Best feed conversion rate was 4.03 for fishes reared in water temperature of 20 ${ }^{0} \mathrm{C}$, while worst feed conversion rate was 5.29 for fishes reared in water temperature of $30{ }^{\circ} \mathrm{C}$ (Figure 5). Statistical analysis of feed conversion rate indicated that there were no significant differences ( $>0.05$ ) between $15{ }^{\circ} \mathrm{C}$ with $20{ }^{\circ} \mathrm{C}$ and $25^{\circ} \mathrm{C}$, while there were significant differences $(\mathrm{p}<0.05)$ between $30{ }^{\circ} \mathrm{C}$ with the other three 
treatments. The best growth criteria were obtained from fishes reared in water temperature of $15{ }^{\circ} \mathrm{C}$ and $20{ }^{\circ} \mathrm{C}$, while worst growth criteria were obtained from fishes reared in water temperature of $30{ }^{\circ} \mathrm{C}$.

Table 1: Average weight of grass carp during the experiment.

\begin{tabular}{|l|c|c|c|c|c|c|c|c|}
\hline \multirow{3}{*}{ Date } & \multicolumn{8}{|c|}{ Grass carp weight $(\mathrm{g} \pm \mathrm{SD})$ in different temperatures $\left({ }^{0} \mathrm{C}\right)$} \\
\cline { 2 - 9 } & \multicolumn{2}{|c|}{15} & \multicolumn{2}{|c|}{20} & \multicolumn{2}{c|}{25} & \multicolumn{2}{c|}{30} \\
\cline { 2 - 9 } & $\mathrm{A} 1$ & $\mathrm{~A} 2$ & $\mathrm{~A} 3$ & $\mathrm{~A} 4$ & $\mathrm{~A} 5$ & $\mathrm{~A} 6$ & $\mathrm{~A} 7$ & $\mathrm{~A} 8$ \\
\hline $7 / 2 / 2021$ & $5.05 \pm 1.19$ & $4.84 \pm 1.50$ & $4.77 \pm 1.44$ & $4.72 \pm 1.46$ & $4.85 \pm 1.37$ & $5.12 \pm 0.79$ & $4.77 \pm 1.22$ & $5.24 \pm 1.55$ \\
\hline $22 / 2$ & $5.51 \pm 1.07$ & $5.36 \pm 1.50$ & $5.08 \pm 1.50$ & $5.17 \pm 1.38$ & $5.14 \pm 1.12$ & $5.56 \pm 0.56$ & $4.85 \pm 1.21$ & $5.46 \pm 1.60$ \\
\hline $8 / 3$ & $6.22 \pm 1.14$ & $6.22 \pm 1.92$ & $5.87 \pm 1.47$ & $6.02 \pm 1.41$ & $5.76 \pm 1.65$ & $6.37 \pm 0.62$ & $5.47 \pm 1.34$ & $6.20 \pm 1.65$ \\
\hline $22 / 3$ & $6.59 \pm 1.44$ & $6.60 \pm 2.11$ & $6.44 \pm 1.65$ & $6.65 \pm 1.63$ & $6.22 \pm 1.97$ & $6.97 \pm 0.87$ & $5.92 \pm 1.53$ & $6.53 \pm 1.83$ \\
\hline $5 / 4$ & $7.34 \pm 1.75$ & $7.3 \pm 2.38$ & $7.05 \pm 1.83$ & $7.21 \pm 1.97$ & $6.92 \pm 2.17$ & $7.33 \pm 1.16$ & $6.47 \pm 1.75$ & $6.99 \pm 1.98$ \\
\hline $19 / 4$ & $8.00 \pm 1.67$ & $7.92 \pm 2.33$ & $7.67 \pm 1.82$ & $7.77 \pm 1.90$ & $7.59 \pm 2.17$ & $7.90 \pm 1.11$ & $7.02 \pm 1.62$ & $7.42 \pm 2.15$ \\
\hline
\end{tabular}

Table 2: Growth criteria of grass carp in different treatments.

\begin{tabular}{|c|c|c|c|c|c|c|c|c|}
\hline \multirow{3}{*}{$\begin{array}{l}\text { Growth } \\
\text { criteria }\end{array}$} & \multicolumn{8}{|c|}{ Treatments for different temperatures $\left({ }^{0} \mathrm{C}\right)$} \\
\hline & \multicolumn{2}{|c|}{15} & \multicolumn{2}{|c|}{20} & \multicolumn{2}{|c|}{25} & \multicolumn{2}{|c|}{30} \\
\hline & A1 & $\mathrm{A} 2$ & A3 & A4 & A5 & A6 & A7 & A8 \\
\hline FW $(\mathrm{g})$ & 8.00 & 7.92 & 7.67 & 7.77 & 7.59 & 7.90 & 7.02 & 7.42 \\
\hline Average & \multicolumn{2}{|c|}{$7.96^{\mathrm{a}}$} & \multicolumn{2}{|c|}{$7.72^{\mathrm{ab}}$} & \multicolumn{2}{|c|}{$7.75^{\mathrm{a}}$} & \multicolumn{2}{|c|}{$7.22^{\mathrm{b}}$} \\
\hline WI (g) & 2.95 & 3.09 & 2.90 & 3.05 & 2.74 & 2.78 & 2.25 & 2.18 \\
\hline Average & \multicolumn{2}{|c|}{$3.02^{\mathrm{a}}$} & \multicolumn{2}{|c|}{$2.97^{\mathrm{ab}}$} & \multicolumn{2}{|c|}{$2.76^{\mathrm{b}}$} & \multicolumn{2}{|c|}{$2.22^{\mathrm{c}}$} \\
\hline DGR (g/day) & 0.0415 & 0.0435 & 0.0408 & 0.0429 & 0.0386 & 0.0392 & 0.0317 & 0.0308 \\
\hline Average & \multicolumn{2}{|c|}{$0.0425^{\mathrm{a}}$} & \multicolumn{2}{|c|}{$0.0419^{\mathrm{ab}}$} & \multicolumn{2}{|c|}{$0.0389^{\mathrm{b}}$} & \multicolumn{2}{|c|}{$0.0312^{\mathrm{c}}$} \\
\hline SGR (\%/day) & 0.6469 & 0.6947 & 0.6688 & 0.7009 & 0.6311 & 0.6111 & 0.544 & 0.4908 \\
\hline Average & \multicolumn{2}{|c|}{$0.6708^{\mathrm{a}}$} & \multicolumn{2}{|c|}{$0.6848^{\mathrm{a}}$} & \multicolumn{2}{|c|}{$0.6211^{\mathrm{a}}$} & \multicolumn{2}{|c|}{$0.5174^{\mathrm{b}}$} \\
\hline FCR & 4.22 & 3.99 & 4.08 & 3.97 & 4.27 & 4.64 & 4.94 & 5.63 \\
\hline Average & \multicolumn{2}{|c|}{$4.10^{\mathrm{a}}$} & \multicolumn{2}{|c|}{$4.03^{\mathrm{a}}$} & \multicolumn{2}{|c|}{$4.46^{\mathrm{a}}$} & \multicolumn{2}{|c|}{$5.29^{\mathrm{b}}$} \\
\hline
\end{tabular}

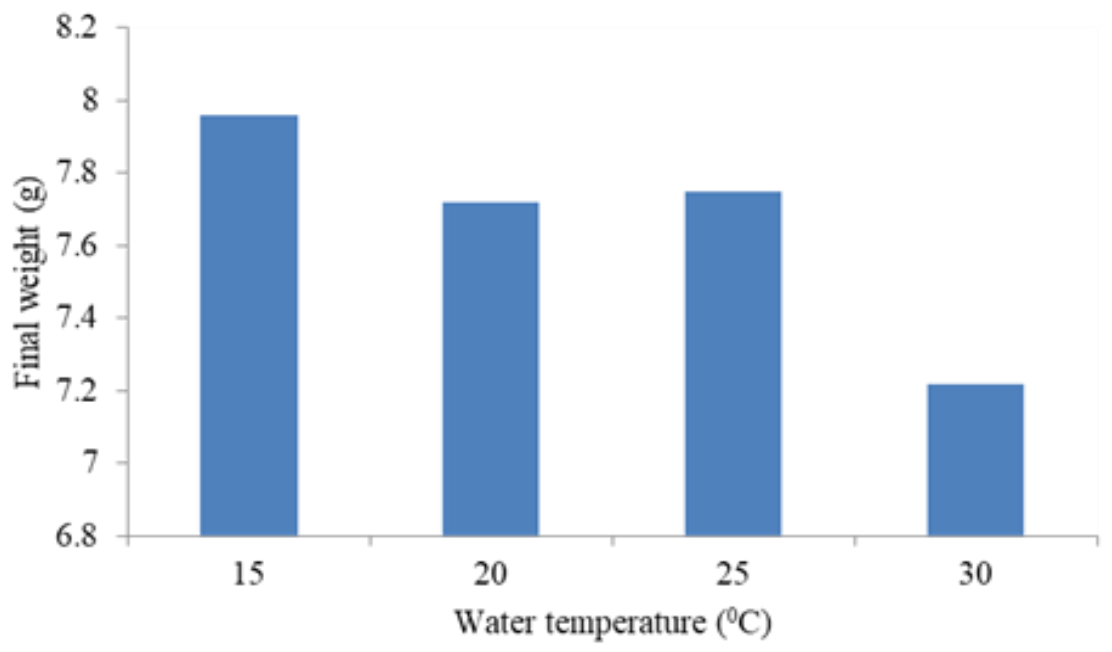

Figure 1: Final weights for fishes reared at different water temperatures. 


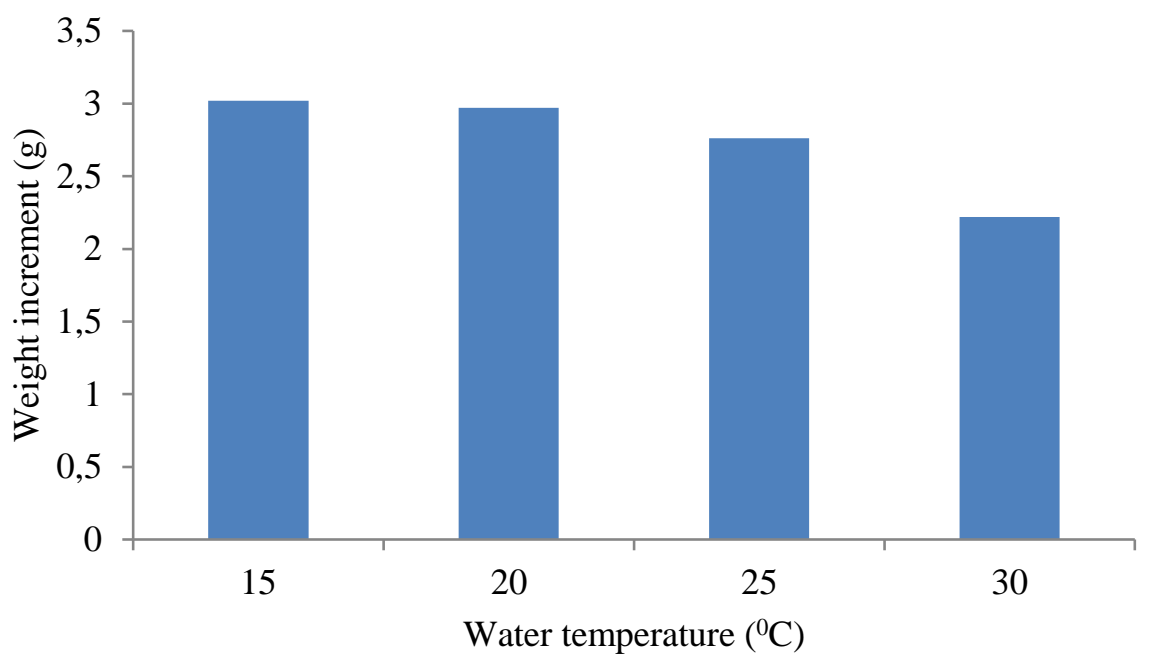

Figure 2: Weight increments for fishes reared at different water temperatures.

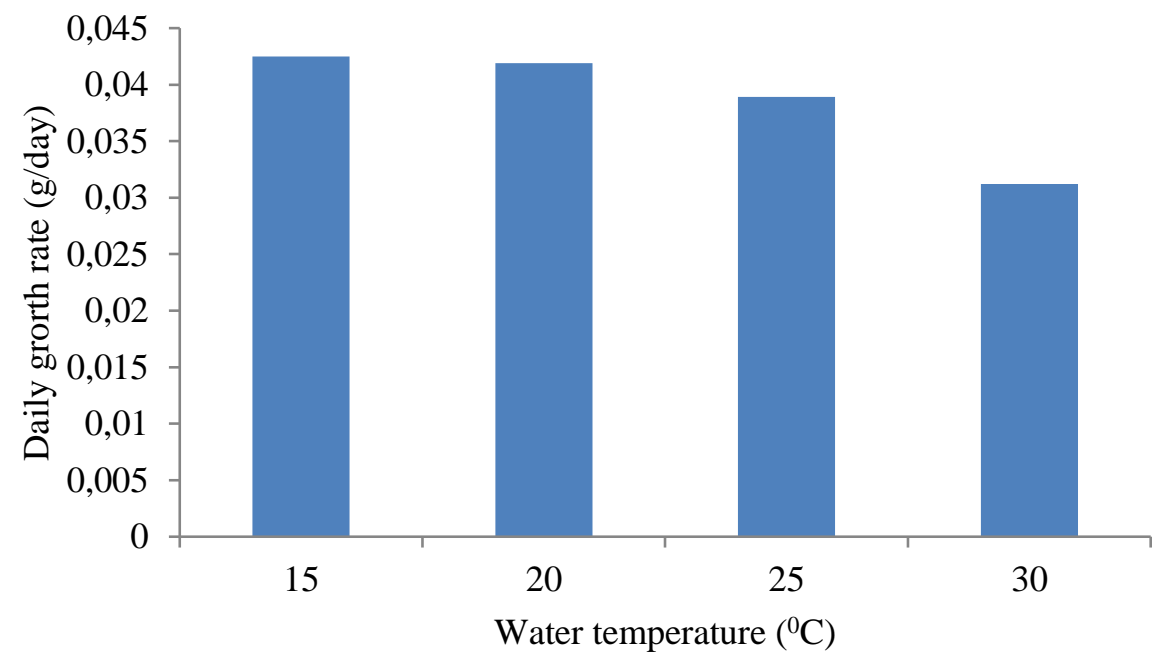

Figure 3: Daily growth rates for fishes reared at different water temperatures. 


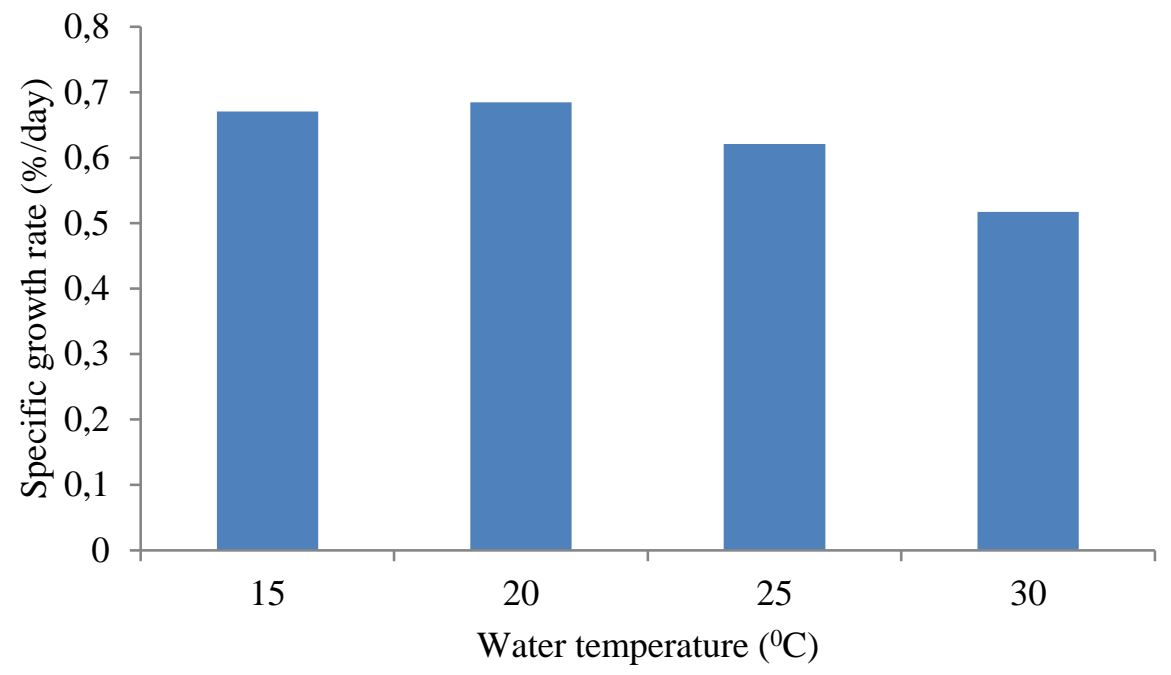

Figure 4: Specific growth rates for fishes reared at different water temperatures.

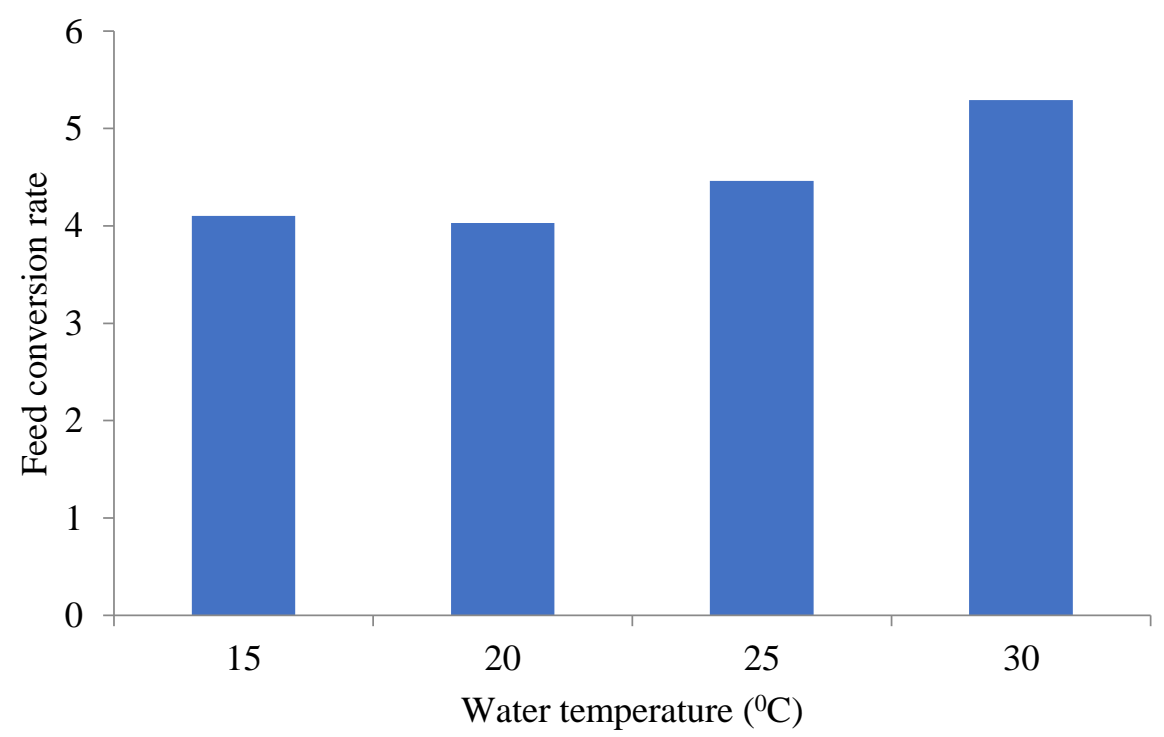

Figure 5: Feed conversion rates for fishes reared at different water temperatures.

\section{Discussion}

Water temperature has long been recognized to affect all activities of poikilothermic animals, including feeding and reproduction. There was a relative positive relationship between water temperature and the growth of most fishes within tolerance limits. Osborne \& Riddle (1999) recorded water temperature and fish size as the main factors affecting the growth of grass carp. 
Results of the current experiment proved that the highest growth of grass carp was reached by fishes reared at water temperatures of $15^{\circ} \mathrm{C}$ and $20{ }^{\circ} \mathrm{C}$, followed by $25{ }^{\circ} \mathrm{C}$, while the lowest growth was reached by fishes reared at $30^{\circ} \mathrm{C}$. Osborne \& Riddle (1999) found that feeding efficiency and weight increments of grass carp increased with increasing water temperature with the better feed conversion rate. Opuszyński (1972) stated that grass carp stopped feeding at a temperature less than $12{ }^{\circ} \mathrm{C}$, while the highest feed consumption occurred at a temperature above $20{ }^{\circ} \mathrm{C}$. Kilambi \& Robinson (1979) reported a water temperature of $18.3-24.9{ }^{\circ} \mathrm{C}$ as optimum for the growth of cultivated grass carp, while Pfeiffer \& Lovell (1990) stated that the optimum range was between $26-30{ }^{\circ} \mathrm{C}$. Masser (2002) reported that grass carp eats vegetation intermittently at low temperature $\left(3^{\circ} \mathrm{C}\right)$ and eats steadily at a range of $10-16^{\circ} \mathrm{C}$, while the optimum feeding occurred at $21-30{ }^{\circ} \mathrm{C}$.

Durborow et al. (2007) pointed out that the highest feed consumption by grass carp occurred between $26.5-29.5^{\circ} \mathrm{C}$ and fish stopped feeding when the temperature was below $12{ }^{\circ} \mathrm{C}$. Taher (2020b) stated that water temperature affected the daily feeding rate of grass carp, and statistical analysis of the average daily feeding rate showed significant differences $(\mathrm{P} \leq 0.05)$ between water temperature $10{ }^{\circ} \mathrm{C}$ with 25 and $30^{\circ} \mathrm{C}$, while there were no significant differences $(\mathrm{P}>0.05)$ between 15 and 20 ${ }^{\circ} \mathrm{C}$. The same previous researcher pointed out that grass carp continued consuming floating pellets even at $10^{\circ} \mathrm{C}$.

Al-Dubakel et al. (2020) recorded growth criteria of grass carp that differed from the current experiment, such as weight increment (1.55-2.50 g), daily growth rate (0.028-0.042 g/day), specific growth rate (0.062-1.000) and very high feed conversion rate (25-40.6). In comparison to the current experiment, Taher (2017) found that grass carp fed pellets had higher weigh increments $(8.14 \mathrm{~g})$ and a higher daily growth rate $(0.17 \mathrm{~g} /$ day $)$. Finally, the ideal water temperature for grass carp cultivation ranged from 15 to less than $30^{\circ} \mathrm{C}$.

\section{References}

Abdullah, J.N.; Taher, M.M. \& Al-Dubakel, A.Y. (2020). Feeding preferences of grass carp (Ctenopharyngodon idella) for three species of aquatic plants. J. Kerbala Agric. Sci., (7)3: 23-34.

Al-Dubakel, A.Y.; Jabir, A.A. \& Al-Hamadany, Q.H. (2011). Growth performance and implication of a thermal-unit growth coefficient of grass carp Ctenopharyngodon idella and silver carp Hypophthalmichthys molitrix larvae reared in recirculation system. J. King Abdulaziz Univ., Mar. Sci., 22(2): 3343. DOI:10.4197/Mar.22-2.3.

Al-Dubakel, A.Y.; Taher, M.M. \& Abdullah, J.N. (2020). Partial replacement of fish meal with Azolla filiculoides meal in the grass carp feed. Biol. Appl. Environ. Res., 4(2): 167-176.

Al-Seyab, A.A.A. (1996). Evaluation of grass carp Ctenopharyngodon idella Val. 1844 efficiency for aquatic weeds control in drainage systems. Ph. D. Thesis, Coll. Agric., Univ. Basrah: 89 pp. (In Arabic). 
Al-Shkakrchy, S.S. \& Ahemed, H.A. (2013). Test duckweed Lemna spp. as a potential food for grass carp Ctenopharhyngodon idella and common carp Cyprinus carpio L. Al-Anbar J. Vet. Sci., 6(1): 44-55.

Bozkurt, Y; Yavas, İ.; Gül, A.; Balc, B.A. \& Çetin, N.C. (2017). Importance of grass carp (Ctenopharyngodon idella) for controlling of aquatic vegetation. Open access peer-reviewed chapter. DOI:10.5772/intechopen.69192.

Cudmore, B. \& Mandrak, N.E. (2004). Biological synopsis of grass carp (Ctenopharyngodon della). Can. Manuscr. Rep. Fish. Aquat. Sci., 2705: v + $44 \mathrm{pp}$.

Dick, G.O.; Smith, D.H.; Schad, A.N. \& Owens, C.S. (2016). Native aquatic vegetation establishment in the presence of triploid grass carp. Lake Reserv. Manage., 32(3): 222-233. DOI:10.1080/10402381.2016.1167147.

Durborow, R.M.; Tucker, C.S.; Gomelsky, B.I.; Onders, R.J. \& Mims, S.D. (2007). Aquatic weed control in ponds. Kentucky State University Aquaculture Program, a KSU Land Grant Program: 21 pp.

FAO (2020). The state of world fisheries and aquaculture. Sustainability in action. Rome. DOI:10.4060/ca9229en.

Kilambi, R.V. \& Robinson, W.R. (1979). Effects of temperature and stocking density on food consumption and growth of grass carp Ctenopharyngodon idella, Val. J. Fish Biol., 15(3): 337-342. DOI:10.1111/j.10958649.1979.tb03614.x.

Kırkağaç, M.U. \& Demir, N. (2006). The effects of grass carp (Ctenopharyngodon idella Val., 1844) on water quality, plankton, macrophytes and benthic macroinvertebrates in a spring pond. Turk. J. Fish. Aquat. Sci., 6: 7-15.

Masser, M.P. (2002). Using grass carp in aquaculture and pond management. Southern Regional Aquaculture Center (SRAC) Publication No. 3600: 4 pp.

Opuszyński, K. (1972). Use of phytophagous fish to control aquatic plants. Aquaculture, 1: 61-74. DOI:10.1016/0044-8486(72)90008-7.

Osborne, J.A. \& Riddle, R.D. (1999). Feeding and growth rates for triploid grass carp as influenced by size and water temperature. J. Freshw. Ecol., 14(1): 4145. DOI:10.1080/02705060.1999.9663653.

Petr, T. (2000). Interactions between fish and aquatic macrophytes in inland waters: A review. In: FAO Fisheries Technical Paper No. 396. Rome, FAO: 185 pp.

Pfeiffer, T.T. \& Lovell, R.T. (1990). Responses of grass carp, stocked intensively in earthen ponds, to various supplemental feeding regimes. Prog. Fish. Cult., 52(4): 213-217. DOI:10.1577/1548-8640(1990)052<0213:ROGCSI $>2.3$. $\mathrm{CO} ; 2$.

Saleh, J.H.; Al-Mukhtar, M.A.; Hsooni, K.H. \& Yasin, A.T. (2008). Culture of grass carp Ctenopharyngodon idella Val. in Fadak Farm- Basrah/ Iraq. Iraqi J. Aquac., 5(1): 13-20. (In Arabic).

Silva, A.F.; Cruz, C.; Pitelli, R.L.C.M. \& Pitelli, R.A. (2014). Use of grass carp (Ctenopharyngodon idella) as a biological control agent for submerged aquatic macrophytes. Planta Daninha, Viçosa-MG, 32(4): 765-773. DOI:10.1590/S0100-83582014000400011. 
Taher, M.M. (2017). Laboratory experiments on cultivation of grass carp Ctenopharyngodon idella (Valenciennes, 1844). Basrah J. Agric. Sci., 30(2): 91-98. DOI:10.37077/25200860.2017.57.

Taher, M.M. (2020a). Effects of fish density on growth and condition factor of grass carp, Ctenopharyngodon idella cultivated in earthen ponds. Marsh Bull., 15(2): 62-72.

Taher, M.M. (2020b). Effects of fish weight and water temperature on feed intake of grass carp, Ctenopharyngodon idella (Cuvier and Valenciennes, 1884). J. Basrah Res. (Sci.), 46(2): 103-114.

Talal, A.-M.H. (2013). A comparative study of grass carp (Ctenopharyngodon idella) when cultivated in polluted and non-polluted aquatic environment. Bas. J. Vet. Res., 12(1): 168-177. DOI:10.33762/BVETR.2013.76199.

Tan, M. \& Armbruster, J.W. (2018). Phylogenetic classification of extant genera of fishes of the order Cypriniformes (Teleostei: Ostariophysi). Zootaxa, 4476 (1): 6-39. DOI:10.11646/zootaxa.4476.1.4. 